\title{
Commodity Housing and the Socio-spatial Structure in Guangzhou
}

A study based on estate-level residential property prices

Ryanne Flock, Werner Breitung and Li Lixun

\section{CpenEdition}

\section{Journals}

Electronic version

URL: http://journals.openedition.org/chinaperspectives/6172

DOI: 10.4000/chinaperspectives.6172

ISSN: 1996-4617

\section{Publisher}

Centre d'étude français sur la Chine contemporaine

Printed version

Date of publication: 1 June 2013

Number of pages: 41-51

ISSN: 2070-3449

\section{Electronic reference}

Ryanne Flock, Werner Breitung and Li Lixun, « Commodity Housing and the Socio-spatial Structure in Guangzhou », China Perspectives [Online], 2013/2 | 2013, Online since 01 June 2016, connection on 28 October 2019. URL : http://journals.openedition.org/chinaperspectives/6172 ; DOI : 10.4000/ chinaperspectives.6172 


\title{
Commodity Housing and the
}

\section{Socio-spatial Structure in Guangzhou}

\author{
A study based on estate-level residential property prices
}

\author{
RYANNE FLOCK, WERNER BREITUNG, AND LI LIXUN ${ }^{(1)}$
}

\begin{abstract}
Commodity housing has become a major engine of urban restructuring and social change in China. It is alleged to aid growing residential segregation and urban fragmentation. In this context, housing price is viewed as an important sorting mechanism. This article investigates this claim by looking at Guangzhou's housing market and analysing data of 797 commercial housing estates. It analyses the development of commodity housing and the trends of housing prices in the city and maps the locational patterns of high, middle, or low housing affordability within this sector.
\end{abstract}

KEYWORDS: Guangzhou, commodity housing, housing prices, segregation, housing reform.

A growing body of recent literature ${ }^{(2)}$ points to the problem of sociospatial differentiation in Chinese cities. The emergence of urban poverty on the one hand and of a growing middle-class on the other hand is not only deepening the wealth gap in society, but is also changing the socio-spatial structure of the respective cities. For a number of authors, ${ }^{(3)}$ the new patterns taking shape are epitomised as "enclave urbanism" in the form of estate-scale neighbourhoods of different social composition, which are juxtaposed to each other and separated by intraurban boundaries. These phenomena are discussed with reference to Western debates on segregation and gated communities or with reference to the political transformation within China. In both cases, the commodification of housing through the post-1978 housing reform plays a major role. Commodity housing was first added to existing housing stock and soon after become the dominant supply mode. We shall now review this process in the particular case of Guangzhou and look at data on commodity housing estates in view of their implications for socio-spatial differentiation and segregation.

When we talk about commodity housing (shangpinfang 商品房), this term first needs explanation. It is not immediately comprehensible without an understanding of the reverse, a centrally planned economy, where housing is not a commodity, but part of the welfare assistance provided by the government to its citizens. When in China such a system was reformed to allow, and soon afterward encourage, private investment in both housing production and housing consumption, the term commodity housing was coined to describe commercial housing as opposed to the old-style welfare housing.

The housing reform started in the early 1980s and gained momentum in the 1990s. At that time, Chinese cities began to grow rapidly, and urban housing was urgently needed. The priorities of Maoist China until then were on industrial build-up rather than urban consumption, which led to a scarcity of housing supply, poor maintenance, and lack of new buildings amid a growing population. ${ }^{(4)}$ As will be detailed below, the reforms promoted by Deng Xiaoping included the opening of the housing sector to commercial actors. First, the production of housing to be distributed through the work units (danwei 单位) was handed to private or quasi-private entities, later consumption was equally liberalised and a housing market emerged.

Very quickly, China has become a society of homeowners. Housing and housing prices have become preferred topics of private conversations and news reports. Commodity housing has become the primary channel for investment, a crucial precondition for marriage and family building, and a marker of individual success and lifestyle. Apart from these cultural meanings, it is also of great macro-economic importance. Public finances largely depend on land sales, and on the relief afforded to public coffers by developers who provide and manage whole neighbourhoods. The real estate sector is a motor of the economy and especially a channel for consumers to spend their surplus wealth domestically. The advantage over competing spending options such as tourism, luxury goods, or cars is that the money stays within the country. Last but not least, the introduction of new housing choices for the middle-class clearly also has the purpose of fostering political stability.

On the other hand, claims arise that this re-evaluation of housing leads to growing socio-spatial differentiation and segregation within China's cities. The dynamics of change are complex and the paths of upward and downward social mobility diverse. Some studies conclude that the winners

1. The research for this article is the outcome of a series of three projects financed by the German Research Foundation (DFC) and led by Prof.W. Breitung (latest project number: BR3546/2-1).

2. Wang Yaping, "Urban poverty, housing and social change in China," Routledge, 2004; Li Zhigang and Wu Fulong, "Tenure-based residential segregation in post-reform Chinese cities: A case study of Shanghai," Transactions of the Institute of British Geographers, Vol. 33, No. 3, 2008, pp. 404419; Wu Fulong and Chris Webster, "Urban poverty in China," Edward Elgar, 2010.

3. Werner Breitung, "Enclave urbanism in China: Attitudes towards gated communities in Guangzhou," Urban Geography, Vol. 33, 2012, pp. 278-294; Bart Wissink, Ronald van Kempen, Fang Yiping, and Li Siming, "Introduction - Living in Chinese enclave cities," Urban Geography, Vol. 33, 2012, pp. 161-166.

4. Xu Xueqiang, "Guangzhou: China's southern gateway," in Victor F.S. Sit (ed.), Chinese cities: The growth of the metropolis, Oxford, Oxford University Press, 1985, pp. 167-187. 
of China's urban housing reform are similar to those of the old system, as former privileges are translated into new wealth. ${ }^{(5)}$ Nevertheless, in the maturing housing market since 2004 , housing prices are seen as becoming the main sorting mechanism.

This paper therefore focuses on housing prices in order to understand the socio-spatial implications of housing commodification in Guangzhou. We are especially interested in claims that the introduction of commodity housing leads to socio-spatial differentiation and segregation. As the vanguard of economic and housing reforms in China, Guangzhou is a good case study, not because it is representative of all Chinese cities, but because of its pioneering role in housing commodification. Many issues observed in Guangzhou have later become relevant for other cities as well. Guangzhou stands out as one of the first Chinese cities that were allowed to introduce market mechanisms and as a place of traditionally strong private entrepreneurship, compared to northern cities with their more statecontrolled economies, it is also a showcase of the trends, chances, and challenges facing all Chinese cities - including the proliferation of commodity housing, related socio-spatial transformations, and the emergence of housing as a social issue.

Methodologically, the value of our case study lies in data on the estate level, which allows us to draw a more fine-grained picture than district or street-level analyses, and in the inclusion of second-hand units, which will increasingly be considered a housing option. Based on a comprehensive data set, we first wanted to find out where in the city commodity housing estates have emerged. Building on this geographical analysis, we then differentiated between estates of different price levels as we investigated the divergence between the low-end and high-end markets and the spatial patterns of commodity estates by price categories. Finally, on a more general level, we want to discuss the implications of commodity housing on the socio-spatial structure of the city. To put this enquiry into context, both internationally and for China, the following section provides a review of related research.

\section{Housing and dynamics of urban fragmentation}

The falling apart of the city is a recurrent theme of urban research, and it has experienced a revival as globalisation, neoliberalism, and post-Fordism have come to be seen as major forces behind urban development. Socioeconomic polarisation and the separation of activity spaces, life styles, and residential space lead to "dual" or otherwise "divided" or "splintered" cities. ${ }^{(6)}$ An important aspect of this is residential segregation, but what exactly this entails and how it can be measured is still disputed. Segregation is commonly defined as "concentration of population groups with a certain characteristic in urban sections/areas." (7) In urban research this is mostly related to the place of residence and characteristics such as nationality, ethnicity, or socio-economic status. ${ }^{\left({ }^{8}\right)}$ It is often measured by dissimilarity indices, ${ }^{(9)}$ although these do not say anything about social relevance or social problems.

In Chinese, "differentiation" (fenyi 分异, fenli 分离) as a term is more commonly used, but it is often presented in context of and interchanged with "segregation" (geli 隔离). Both are generally viewed negatively, with blurry moral reasoning and reference to Western cases. Especially after the national introduction of the concept of "harmonious society," Chinese research on segregation gained not only momentum but also ideological context. ${ }^{(10)}$ What appears special today stands against the background of the Maoist past. The socialist city was formed by a planned economy, which led to a broad distribution of similar industries, functions, and facilities over the city. The state allocated housing through the danwei and put workers, supervisors, and cadres into the same neighbourhoods. In the end, it was not so much characteristics of the individual as those of the workplace that determined the living environment. But residential differentiation of the population produced by danwei hierarchy is seldom considered. Instead, the implicit starting point in many studies is the "typical homogeneity" (11) of the Chinese city before the reform and opening policies: "China's society is going from the equality of the past towards differentiation [...] and residential segregation." (12)

Most Chinese work on differentiation/segregation concentrates on explaining the reasons for the emerging differentiation - systemic and individual. Economic and social transformation, globalisation and a widening income gap build the background; profit-oriented mechanisms of urban development, urban planning, the hukou (户口), and the welfare housing system as well as increasing individual mobility and housing preferences are mentioned as concrete mechanisms. ${ }^{(13)}$ Most empirical data are produced by directly approaching poor or rich areas - urbanised villages, migrant enclaves, old neighbourhoods of laid-off workers, danwei housing, gated communities for higher income groups, etc. However, this can only cover small parts of a city.

General overviews on socio-spatial differentiation are challenged by the lack of statistical data. Most comprehensive data can be found in the national census surveys, but information on income is only available as average data on the municipal level. ${ }^{(14)}$ Therefore, studies switch to other

5. John Logan et al., "The winners of China's urban housing reform," Housing Studies, Vol. 25, No. 1, 2010, pp. 101-117; Li Siming, "Housing tenure and residential mobility in urban China: A study of commodity housing development in Beijing and Guangzhou," Urban Affairs Review, Vol. 38, No. 4, 2003, pp. 510-534; Wang Feng, "Housing improvement and distribution in urban China: Initial evidence from China's 2000 census," The China Review, Vol. 3, No. 2, 2003, pp. 121-143.

6. John H. Mollenkopf and Manuel Castells, Dual City: Restructuring New York, New York, Russell Sage Foundation, 1991; Susan S. Fainstein et al., Divided Cities: New York \& London in the Contemporary World, Oxford, Blackwell Publishers, 1992.

7. Hartmut Häußermann, "Wohnen und Quartier: Ursachen sozialräumlicher Segregation" (Dwelling and neighbourhood: origins of socio-spatial segregation), in Ernst-Ulrich Huster et al. (eds.), Handbuch Armut und Soziale Ausgrenzung (Reader on poverty and social exclusion), Verlag für Sozialwissenschaften, 2008, p. 336.

8. Robert Vanderbeck, "Segregation," in Barney Warf (ed.), Encyclopedia of human geography, Sage Publications, 2006, p. 423.

9. Li Zhigang and Wu Fulong, "Tenure-based residential segregation in post-reform Chinese cities: A case study of Shanghai," op. cit.

10. Sun Bindong and Wu Yafei, "Zhongguo chengshi juzhu kongjian fenyi yanjiu de jinzhan yu zhanwang" (Progress and prospects of research on residential spatial differentiation in Chinese cities), Chengshi Guihua, Vol. 33, No. 6, 2009, pp. 73-80: pp. 74, 77.

11. Feng Jian and Zhou Yixing, "Beijing dushiqu shehui kongjian jiegou ji qi yanhua (1982-2000)" (The social spatial structure of the Beijing metropolitan area and its evolution [1982-2000]), Dili Yanjiu, Vol. 22, No. 4, pp. 465-483: p. 483.

12. Huang Youqin, "Cong danwei dayuan dao fengbi shi shequ - zhidu zhuanxing guocheng zhong Beijing de zhufang yu juzhu bianhua" (From danwei housing to gated communities - Changes in housing and dwelling in Beijing during the systemic transformation process), in Wu Fulong et al. (eds.), Zhuanxing yu chonggou: Zhongguo chengshi fazhan duowei toushi (Transformation and reconstruction: A multidimensional perspective on China's urban development), Dongnan daxue chubanshe, 2007, pp. 199-220, p. 216.

13. Sun Bindong and Wu Yafei, "Zhongguo chengshi juzhu kongjian fenyi yanjiu de jinzhan yu zhanwang," op. cit., pp. 76 ff; Xuan Guofu, Zhuangxing shiqi Zhongguo da chengshi shehui kongjian jiegou yanjiu (Study on the structure of social space of big cities in China during the transformation period), Dongnan daxue chubanshe, 2010; Yang Shangguang, Zhongguo da chengshi shehui kongjian de yanhua (Evolution of social space in Chinese metropolis), Huadong ligong daxue chubanshe, 2006

14. Li Zhigang and Wu Fulong, "Tenure-based residential segregation in post-reform Chinese cities: A case study of Shanghai," op. cit., p. 409. 


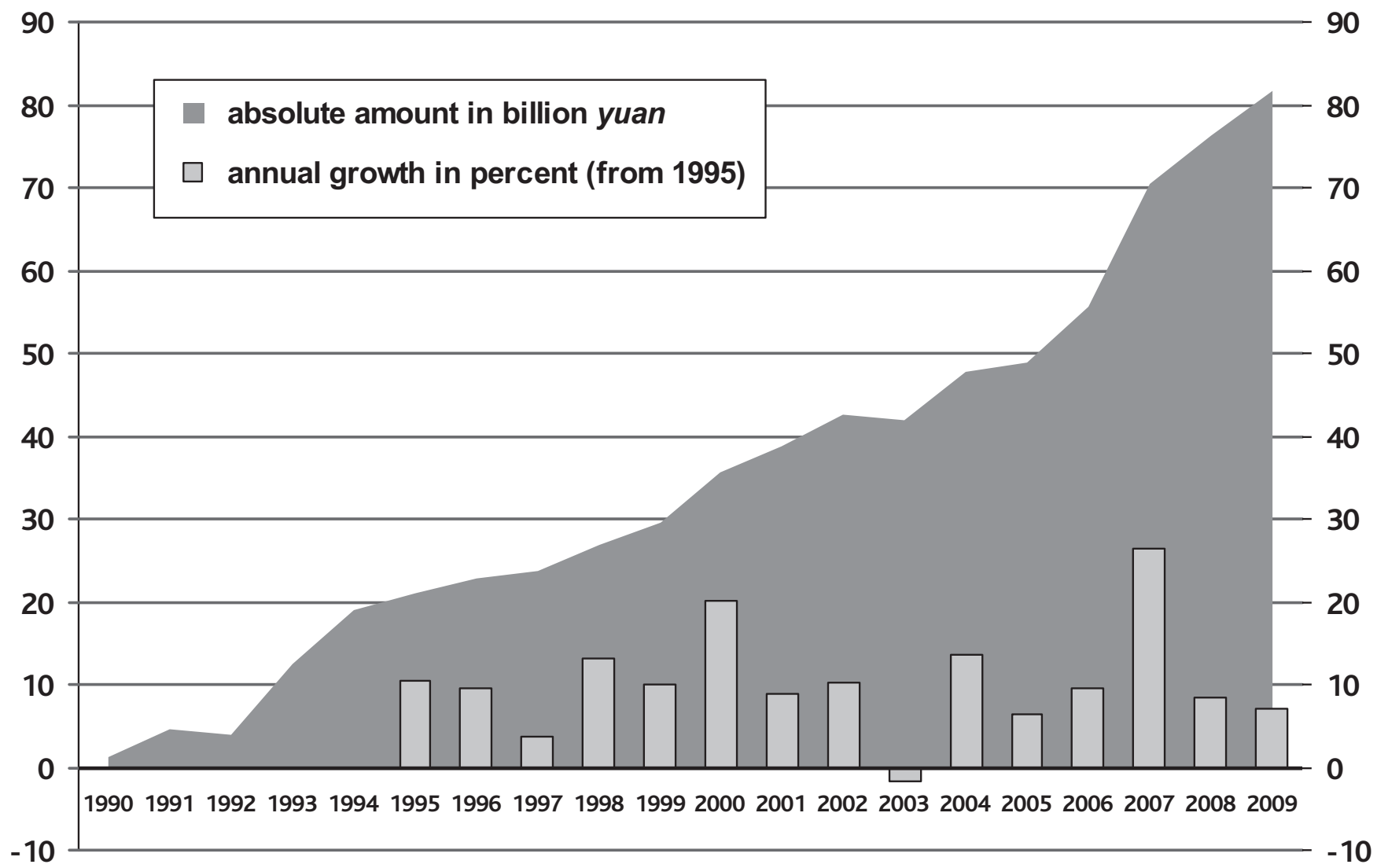

Sources: Liang Xuebin (ed.), Guangzhou dichan ershinian, 1985-2005 (20 years real estate in Guangzhou, 1985-2005), Guangzhoushi fangdichan xiehui, 2005; Guangzou tongjiju xinxiwang: www.gzstats.gov.cn.

household information available on the street committee level, although this scale may also not be detailed enough. Based on the $5^{\text {th }}$ Census of 2000, Xuan identified six types of areas in Shanghai with spatially concentrated characteristics: old building stock with older inhabitants, high socio-economic status, danwei housing, newly build housing, migrant status, and rural hukou. ${ }^{(15)} \mathrm{Li}$ and Wu (2008) calculate with similar data the dissimilarity index and show a higher degree of segregation between local hukou holders and short-term migrants, as well as between private and public housing in Shanghai. (16) Various studies focus on the spatial distribution of housing types to get a clearer picture (danwei housing, commodity housing, etc.), but often with quite descriptive results. (17) Since commodity housing is emerging as the dominant housing type, the differentiation within this type becomes increasingly relevant. Based on the assumption of housing prices as an important sorting mechanism, it has become common to investigate socio-spatial differentiation between high and low-priced estates via differentiation indices. ${ }^{(18)} \mathrm{Wu}$ uses such data to conclude that "the foremost impact of housing commodification is the revitalisation of the pre-socialist spatial division" (19) of Shanghai. Others use maps and visualise patterns of price types to argue for concentration. Unfortunately, they give only a rough impression of their distribution. They show bigger, homogeneous areas, either by collecting data on a higher scale or by merging the defined neighbourhood types, ignoring what might lie in between. ${ }^{(20)}$ With our data we want to point to a more differentiated reality.

\section{Development of commodity housing in Guangzhou}

\section{Early phase of housing commodification}

In China's socialist housing system, the allocation of residential space through the danwei and municipal housing bureaus to registered urban citizens left almost no choice in housing consumption. Housing conditions depended on the status of the danwei in the governmental hierarchy, status within the danwei, relationships to gatekeepers, and membership in the

15. Xuan Guofu, Zhuangxing shiqi Zhongguo da chengshi shehui kongjian jiegou yanjiu, op. cit., p. 158.

16. Li Zhigang and Wu Fulong, "Tenure-based residential segregation in post-reform Chinese cities: A case study of Shanghai," op. cit.

17. Yang Shangguang, Zhongguo da chengshi shehui kongjian de yanhua, op. cit., pp. 126 ff; Xing Lanqin et al.,"1990 niandai yilai Xi'an chengshi juzhu kongjian chonggou yu fenyi" (Reconstruction and differentiation of residential space in Xi'an city since the 1999s), Juzhu kongjian fenyi chutan, Vol. 28, No. 6, 2004, pp. 68-73.

18. Sun Bindong and Wu Yafei, "Zhongguo chengshi juzhu kongjian fenyi yanjiu de jinzhan yu zhanwang," op. cit., Xing Lanqin et al.,"1990 niandai yilai Xi'an chengshi juzhu kongjian chonggou yu fenyi," op. cit.

19. Wu Fulong, "Sociospatial differentiation in urban China: Evidence from Shanghai's real estate markets," Environment and Planning A, Vol. 34, 2002, p. 1612.

20. Yang Shangguang, Zhongguo da chengshi shehui kongjian de yanhua, op. cit., pp. $126 \mathrm{ff}$; Li Xueming et al., "Dalian shangpin zhuzhai jiage kongjian fenyi guilü yanjiu" (Research on the regular pattern of spatial differentiation of commercial housing prices in Dalian), Diyu yanjiu yu kaifa, Vol. 23, No. 6, 2004, pp. 35-39; Huang Jiqiao, "Shanghai shi zhongxin chengqu juzhu kongjian jiegou de yanbian" (On the structure change of residential space in Shanghai's central districts), Chengshi wenti, No. 4, 2001, pp. 30-34, 37. 
Communist Party. (21) This started to change more than ten years after the $9^{\text {th }}$ National Congress calling for opening and reforms, when the "Implementation Plan for Housing System Reform in Guangzhou" (Guangzhou Shi zhufang zhidu gaige shishi fang'an) was issued. In October 1989 , it kicked off a new housing provision system in Guangzhou as one of the 80 major cities that were allowed to experiment with reforms. ${ }^{(22)}$

Enforcement began slowly, but gained momentum with Deng Xiaoping's southern tour and his promotion of reforms in 1992. However, it was the "Decision on Deepening the Urban Housing Reform System in Guangzhou City" (Guangzhou shi shenhua zhufang zhidu gaige shishi yijian) in 1995 that gave clearer directions. (23) Still far from a market with an "invisible hand," the reforms set incentives and introduced competition. Crucially, the state still retained ownership of land, but land use rights became transferable for a limited time. (24) The roles of the work unit and the municipal financing bureau for housing provision were taken over by developers, real estate agents, a reformed banking system, foreign investors, and municipal governments as landlords. ${ }^{(25)}$

New supply was now either commodity housing or subsidised housing. The latter included "economical" and "suitable" houses, also known as "houses to relieve distress" (jiekunfang 解困房) or "projects for a peaceful living" (anju gongcheng 安居工程) aiming at middle and low-income groups. (26) They were mostly sold at net cost price (chengbenjia 成本价), excluding various taxes, insurance, and other fees as well as developer profits. The same goes for reform housing: former danwei houses that have been privatised (in Guangzhou since the end of the 1980s) at net cost prices largely fixed by the government. Some work units have reduced the price further, in accordance with their resources, the employer's status, or the age of the house. (27)

These programmes stood in contrast to the purely commercial commodity-housing sector, but both affected each other's price levels, because they partly attracted the same clientele. Whereas in Guangzhou not more than 30,000 families had actually joined any social housing scheme by the end of the 1990s, ${ }^{(28)}$ the work units still played a major role. During the 1990s, they built half of the residential stock ${ }^{(29)}$ and additionally bought commodity apartments to sell to their employees. ${ }^{(30)}$ Thus, access to housing not only depended on the household's buying-power, but still also on the work unit and one's position within it.

Nevertheless, in comparison to other cities, the share of individual property purchase was unusually high in Guangzhou. It stood at around $46 \%$ of all real estate transactions in 1990 and at $64 \%$ in 1997. Financial help at least for workers in state-owned enterprises - was meant to come from the housing provident fund set up in April 1992, (31) but in the 1990s, as many as $54 \%$ of the purchasers of commodity housing and $69 \%$ of subsidised housing relied on personal savings, and 30\% and $22 \%$ respectively on financial assistance from their parents. Only a few buyers used bank loans (7\% and 2.5\%), and even fewer the housing provident fund. Guangzhou's commodity housing demand was therefore strongly based on existing wealth.

The state encouraged real estate investment. Assertions by Deng Xiaoping and Guangzhou's plan in the early 1990s to "fundamentally modernise within 15 years" (32) boosted the confidence of investors. The city consequently witnessed an unprecedented housing boom (Figure 1). Investments in housing surged from 390,000 yuan in 1992 to 1.25 million yuan in 1993. About half of these investments went into the construction of new apartments. Residential space therefore expanded by 4.37 million sq. meters or $14.5 \%$ annually from 1995 to $1997 .{ }^{(33)}$ As in other Chinese cities, the years from 1994 to 1997 were a time of overheating and overconstruction, especially of high-end apartments and office space. ${ }^{(34)}$ At the end of the 1990s, the vacancy rate of commodity buildings stood at $58.4 \%$ and of commodity housing at $20.9 \%$. ${ }^{(35)}$ As a consequence of policies and market developments, prices of commodity housing surged by about $140 \%$ within four years (1992-1996).

\section{Commodity housing as default mode of supply}

The full privatisation of housing was already intended in the early days of housing reform, but the Asian Crisis of 1997 was the crucial ignition spark to proceed further. Although the crisis had only limited impact on China, it still slowed down the economy, ${ }^{(36)}$ and investors withdrew their capital from the real estate market as well. Among the measures to revive the economy was the far-reaching decision to end in-kind distribution of housing in 1998 and replace it with monetary government grants. Thus consumers had to orientate themselves to the market. At the same time, the mortgage system expanded and an increasing number of people had access to loans via the housing provident fund or banks, now with better conditions. At least for

21. Li Siming and Siu Yatmin, "Residential mobility and urban restructuring under market transition: A study of Guangzhou, China," Professional Geographer, Vol. 53, No. 2, 2001, pp. 219-29.

22. Wang Yaping and Alan Murie, "The process of commercialisation of urban housing in China," Urban Studies, Vol. 33, No. 6, 1996, p. 978; Guangzhou fangdichanzhi (Chronicles of Guangzhou's real estate development), Guangdong keji chubanshe, 1990, p. 64.

23. "Guangzhou shi shenhua zhufang zhidu gaige shishi yijian" (Decision on deepening the urban housing reform system in Guangzhou City), 1 July 1995, www.guangzhou.gov.cn/yearbook/ 20year/html/16840.htm (accessed on 11 April 2013).

24. Fung Hung-Gay et al., "The development of the real estate industry in China," The Chinese Economy, Vol. 39, No. 1, 2006, p. 84.

25. Wang Yaping and Alan Murie, "The process of commercialisation of urban housing in China," op. cit., p. 978 ff; Dai Zhiguo (ed.), Guangzhou Fangdichan zonglan (Understanding Guangzhou's real estate), Gaige chubanshe, 1997, p. 42.

26. Zhu Guifeng, "Guangzhou chongqi jingji shiyong fang jihua" (Guangzhou begins again: A plan for economical and suitable houses), Zhongguo guotu ziyuan bao, 7 February 2006, p. 5; "Guli anju Guangzhou 4 nian nei zai jian wanyu tao jingji shiyong fang" (Enlivening the projects for a peaceful living - Guangzhou builds more than 10,000 new economical and suitable houses within four years), Zhongguo xinxibao, 27 June 2000, p. 1.

27. Guangzhou Fangdichan Guanliju, Guangzhou fangdichanzhi, op. cit., p. 64; "Guangzhou shi shenhua zhufang zhidu gaige shishi yijian" (Decision on deepening the urban housing reform system in Guangzhou City), op. cit.; Chen Aimin, "China's urban housing: privatization and market integration," in Chen Aimin et al. (eds.), Urbanization and Social Welfare in China, Ashgate, 2004, p. 66.

28. Zhu Guifeng, "Guangzhou chongqi jingji shiyong fang jihua," op. cit:; "Guli anju - Guangzhou 4 nian nei zai jian wanyu tao jingji shiyong fang," op. cit.

29. Zheng Zhenwei, "Guangzhou shi fangjia shangsheng de yuanyin ji xianjiafang zhengce yanjiu," in Shu Yang and Jian Wenhao (eds.), Guangzhou chengshi jianshe fazhan baogao (2008) (Annual report on Guangzhou's urban construction [2008]), Shehui kexue wenxian chubanshe, 2008, p. 219.

30. Ma Yaodong et al., "Analysis on the present situation and contributing factors of vacant commercial housing in Guangzhou urban district," Chinese Geographical Science, Vol. 13, No. 2, 2003, p. 186.

31. Wang Yaping and Alan Murie, "The process of commercialisation of urban housing in China," op. cit., Pp. $979 \mathrm{ff}$.

32. Gu Jianqing, "Da dushi guanghuan xia Guangzhou fangdichanye" (Guangzhou's real estate business in the light of the big city), Dushi jingji, No. 11/12, 1995, pp. 64-67.

33. Liang Xuebin (ed.), Guangzhou fangdichan ershi nian, 1985-2005 (20 years real estate in Guangzhou, 1985-2005), Guangzhoushi fangdichan xiehui, 2005, p. 130.

34. Raymond Tse, "The real estate values in China: Lessons of the late 1990s," The Appraisal Journal, Vol. 70, January, 2002, p. 23; Ma Yaodong et al.," Analysis on the present situation and contributing factors of vacant commercial housing in Guangzhou urban district," op. cit., p. 184.

35. Zhou Chunshan et al., "Guangzhou shi shangpin zhuzhai bushu zhuangkuang yu chengyin fenxi," op. cit., p. 690.

36. Raymond Tse, "China's real estate market and the Asian Financial Crisis," The Emerging Markets Quarterly, Winter, 2000, pp. 1-9. 
purchasers of commodity housing, bank loans played a bigger role $(16.7 \%) \cdot{ }^{(37)}$

When the danwei retrenched as a producer of housing, its share of built residential area fell from $46.1 \%$ in 1998 to $12.1 \%$ in 2006 . The $81.4 \%$ individual buyers of commodity housing in 2001 boosted diversification of Guangzhou's real estate supply and demand. (38) Thus, in the first years after the Asian Crisis the growth rates of investment in completed commodity housing were high, and new houses continued to come up all over the city. In 2002, investment in real estate development became the primary stimulant of investments in fixed assets in the city. Investment in residential projects accounted for over $70 \%$ of overall real estate investment. Expediently, China's new membership in the World Trade Organization (WTO) in 2001 ended restrictions on foreign investment in real estate and increased demand from the international business sector. ${ }^{(39)}$

Problematic, however, was the high vacancy rate of $23.5 \%$ (2003), ${ }^{(40)}$ which led to a $33 \%$ drop in prices to ca. 4,600 yuan $/ \mathrm{m}^{2}$ for first-hand transactions. Concerned about over-construction on the one hand and scarcity of farm land on the other hand, the government put more restrictions on real estate development and especially land expropriation. ${ }^{(41)}$ The consequence was a radical withdrawal of investment from real estate in 2003 (Figure 1).

\section{The emergence of a second-hand market}

The developments of the early 2000s also invigorated the previously often ignored second-hand market in both commodity and privatised housing. It was during the Asian Crisis of 1997 that many investors first shed their new dwellings and put them up for sale. This partly explains the afore-mentioned price stagnation, because "used" homes cost only a fraction of new ones. At the same time, the government fought the crisis by simplifying purchase procedures for this market segment, reducing fees and taxes, and expanding the mortgage and loan system. In 1998, the trade in second-hand housing doubled within a year. ${ }^{(42)}$ Former danwei housing entered the second-hand market as work units started selling their housing stock to sitting tenants. Guangzhou stood out among Chinese cities in that the purchase of these units already included full property rights, and reselling was possible after five years. ${ }^{(43)}$ This kind of housing still made up only $4.4 \%$ of the secondhand market in 1999 , but already by 2004 , when only $8 \%$ of the work unit housing stock was sold, it accounted for $20.4 \%$. ${ }^{(44)}$

Second-hand housing continues to grow in importance. The ratio between newly-built to used housing was 3:1 in 2001, but decreased to 1:1 by 2009. (45) Former danwei housing in particular is becoming a relevant factor. Ma et al. (2010) found that in 2005, among the examined households (with household heads between 20 and 55 years old), 55\% opted for former danwei units, and only $25 \%$ bought into commodity housing. The same source also quoted a 2005 survey by the real estate company MyTopHome (man tang hong 满堂红) indicating that $91.5 \%$ of second-hand buyers bought for their own use, and only a few intended to rent out or resell. (46) Second-hand prices meanwhile remained relatively low. In 2009, they stood at 7,319 yuan $/ \mathrm{m}^{2}$ on average, with Tianhe $\left(13,066 \mathrm{yuan} / \mathrm{m}^{2}\right)$ the most expensive and Huadu $\left(3,917\right.$ yuan $\left./ \mathrm{m}^{2}\right)$ the cheapest district. ${ }^{(47)}$

\section{Price hikes and the affordability dilemma}

First-hand property prices resumed their rapid growth in the mid-2000s. Due to the abolition of welfare housing, increased land prices, growing speculation, and stimulus measures introduced in $2004,(48)$ the price of new commodity residential units in urban Guangzhou surged from 5,278 yuan $/ \mathrm{m}^{2}$ in December 2005 to 7,205 yuan/m² in December 2006 and 15,000 yuan/ $\mathrm{m}^{2}$ in October 2007. ${ }^{(49)}$ In response, the government tried to cool down the economy, but unfortunately this coincided with the global financial crisis of 2008. (50) Property prices eased at the end of 2007 and stagnated at around 9,400 yuan $/ \mathrm{m}^{2}$ in the following years before rising again to 11,874 yuan $/ \mathrm{m}^{2}$ in the second quarter of 2010. ${ }^{(51)}$

Looking beyond the market fluctuations explained above, square meter prices generally increased due to land scarcity, land prices, development costs, inflation, and expected inflation. Additionally, the relative inelasticity of consumers demand has to be taken into account. To buy a house in China is not merely one option among various forms of housing consumption but rather a cultural imperative: there is no talk of settling down, marrying, or retiring without owning an apartment. Especially for men, status on the marriage market is strongly correlated with purchasing power on the housing market. The pressure is built up not only by potential wives, but also by the social environment, parents, and relatives. "Housing is the material symbol of having a family and has always been viewed as the source of safety and happiness in Chinese life." (52) In addition to that, housing is seen as a wise investment, a secure pillar within a time of economic transformation. This leads to an interesting paradox. On the one hand, housing prices have to be low to embark on the desired course of life; on the other hand, prices have to increase to fulfil promises of socioeconomic upward mobility.

37. Fung Hung-Gay et al., "Development of China's real estate market," op. cit., p. 73; Li Siming and ZhengYi, "Financing home purchase in China, with special reference to Guangzhou," op. cit., p. 420.

38. Zheng Zhenwei, "Guangzhou shi fangjia shangsheng de yuanyin ji xianjiafang zhengce yanjiu," op. cit., pp. 217-19.

39. He Canfei et al., "What attracts foreign direct investment in China's real estate development?", Annals of Regional Science, Vol. 46, No. 2, 2011, pp. 267-293.

40. Gao Jianghong, "Guangzhou shangpinfang kongzhilü yuan chao jingjiexian - shichang keneng hui bengkui" (The vacancy rate of Guangzhou's commercial housing exceeds the warning level - the market might break down), original data source Xinxi shibao, 2006, www.nj.focus.cn/news/200605-10/203988.html (accessed on 12 February 2013); Ming Juan and Wang Zicheng, "Guangzhou fangdichan paomo shizheng yanjiu" (Research on proofing Guangzhou's real estate bubble), Jingji yanjiu daokan, No. 7, 2006, p. 128.

41. Fung Hung-Gay et al., "Development of China's real estate market," op. cit., p. 73.

42. Ibid., p. 99.

43. "Guangzhou shi shenhua zhufang zhidu gaige shishi yijian," op. cit.

44. Liang Xuebin (ed.), Guangzhou dichan ershi nian, 1985-2005, op. cit., pp. 99 ff.

45. Ibid., p. 4

46. Ma Zhongdong et al., "Shichanghua xia chengshi jumin de zhufang xuanze: yi Guangzhou wei li" (Urban residents' housing choices under marketisation: Taking Guangzhou as example), Renkou yu fazhan, Vol. 16, No. 2, 2010, p. 102.

47. Hope Real Property (ed.), Guangzhou ershoufang baipishu (White book of Guangzhou's second hand housing), Hefu zhiye, 2010, pp. 4 ff.

48. Huang Suicheng, "Guangzhou: dui chongqi jingji shiyongfang jianshe de fansi," op. cit., p. 30; Yung Ka Man, A comparative study of the real estate market in Beijing, Guangzhou and Shanghai: Reform, development \& prospect, unpublished master thesis, University of Hong Kong, China Area Studies, 2003, p. 81; Fung Hung-Gay et al., "Development of China's Real Estate Market," op. cit., p. 73 .

49. Zheng Zhenwei, "Guangzhou shi fangjia shangsheng de yuanyin ji xianjiafang zhengce yanjiu," op. cit., pp. $219 \mathrm{ff}$. (calculated as average for the six central districts).

50. Margot Schüller, "China in der globalen Finanzkrise: Wirtschaftspolitische Strategien und Strukturprobleme" (China at the global financial crisis: Politico-economic strategies and structural problems), GIGA Fokus, No. 4, 2009, pp. 1-7; Xiao Wenxiao, "2008 nian Guangzhou fangdichan shichang zongjie ji 2009 nian zhanwang" (Summary of Guangzhou's real estate market 2008 and expectations for 2009), Zhongguo fangdi xinxi, No. 1, 2009, pp. 54-57.

51. Price statistics: Guangzhou Tongjiju Yangguang Jiayuan, www.g4c.laho.cov.cn/index.htm.

52. Tong Zhongyi, and R. Allen Hays, "The Transformation of the Urban Housing System in China," Urban Affairs Review, Vol. 31, No. 5, 1996, pp. 625-658. 
As a consequence, discussions about subsidised housing resurface both in times of rising prices and in times of economic hardship. ${ }^{(53)}$ The State Council's 2008 stimulus package (besides generous fiscal and monetary policies and increased infrastructure investments) also included measures to promote the second-hand market and affordable housing. ${ }^{(54)}$ Guangzhou expanded its programme of subsidised housing by rent support (lianzu zhufang 廉租住房) and economic and suitable houses to help the lower income class. Limited-priced houses (xianjia fang 限价房) target the "sandwich class" (jiaxin ceng 夹心层), lower and middle-class families that cannot afford to buy a house but are not entitled to government allowances.

While according to the yearbooks, in 2008 and 2009 limited-price housing absorbed about $6 \%$ of all investments in residential units, ${ }^{(55)}$ newspapers reported that when finished these houses were partly redefined as other types of social housing or sold as commodity housing. ${ }^{(56)}$ By the time of our survey in 2008, social housing did not play any major role in Guangzhou, but in recent years some new clusters of mainly subsidised rental housing have emerged. Most of them are located on the fringe of the inner city. ${ }^{(57)}$

\section{Data and methodology}

\section{Data}

Before presenting our data sources and discussing the spatial distribution of commodity housing estates in Guangzhou, we need to revisit the term "commodity housing" in more detail. Unfortunately, the use of this term is not always consistent. It is often understood in contrast to categories such as "economical suitable housing" (jingji shiyong fang 经济适用房) or "reform housing" (fanggai fang 房改房), (58) but sometimes also as including commercially-built housing distributed through work units, housing bureaus, etc. ${ }^{(59)}$ Although the term is linked to the privatisation of real estate, newer yearbooks include subsidised housing (baozhang xing zhufang 保障性住房) as part of commodity housing. ${ }^{(60)}$ Older yearbooks provide data on the size of new units only for shangpinfang, though they might be calculated in a similar way. The category shangpinfang actually includes not only residential space but also office buildings and commercial premises. ${ }^{(61)}$ We therefore translate shangpinfang as commodity buildings and refer to shangpin zhuzhai (商品住宅) or shangpin zhufang (商品住房) as commodity housing. There may also be some confusion regarding the translation of "fang" as housing, but we emphasise that we refer to commercial residential space.

Our data on Guangzhou's commodity housing estates is derived from four known real estate agent websites (Soufun.com Ltd., Anjuke Inc., Sohu.com Inc., Fangjiawang). ${ }^{(62)}$ They differ slightly from each other in the number of available housing units and also in the amount of information and specifics in the respective search engines, and therefore complement each other. From these websites, we extracted the names, addresses, average square meter prices, and ages of all commodity housing estates in Guangzhou selling apartments at the time of access in December 2008. These totalled 797 estates, which had entered the market from 1993 to 2008. The age notably represents the age of the estate, not the age of the building. Apartments on offer in an older estate may include both second-hand units and buildings recently added. The average square-meter prices per estate were extracted directly from the websites and not calculated by us. Presumably they were calculated from the total of all units on offer. They therefore do not reflect differentiation within the estate, but they should reflect the overall status of the estate.
Another caveat is that units offered through the websites may be bought by people who subsequently do not move in. They might well leave them empty, provide them to relatives, or rent them out. Due to the high demand for housing in Guangzhou, we can assume that most of the shown estates are subsequently occupied, but we cannot be sure about the homogeneity of the people moving in. Households in upmarket estates need resources such as wealth, income, status, or connections, yet renters could to some extent increase the social heterogeneity of the estates. In short, our data is really estate-level, not household- or building-level data.

The prices also require some discussion. They are asking prices, not the actually paid prices, and they represent a snapshot, not a long-term average. For both reasons, we need to question the validity of our approach especially since 2008 was the year of the financial crisis. It turns out, however, that the annual average prices did not deviate much from the long-term trend. ${ }^{(63)}$ In contrast to that, monthly volatility made 2008 quite a turbulent year, but December, when the data of this sample was collected, shows only slight deviance from the annual average. The December average was 8,012 yuan $/ \mathrm{m}^{2}$ for first-hand and 4,424 yuan $/ \mathrm{m}^{2}$ for second-hand housing, compared to the 2008 annual average of 9,339 yuan $/ \mathrm{m}^{2}$ and 4,378 yuan $/ \mathrm{m}^{2}$ respectively. Our sample recorded average prices of 11,291 yuan $/ \mathrm{m}^{2}$ and $5,950 \mathrm{yuan} / \mathrm{m}^{2}$. This discrepancy of about $20 \%$ compared to the annual average can be partly explained by the different price types. Our sample uses asking prices (baojia 报价) on real estate websites, whereas

53. Huang Guangyi, Guangzhoushi xianjiafang zhengce shishi zhong cunzai wenti yu duice yanjiu (Research on problems and solutions for the implementation of the limited price housing policy in Guangzhou), unpublished master thesis, Sun Yatsen University, Public Administration, 2009, pp. 11-14.

54. Margot Schüller, "China in der globalen Finanzkrise: Wirtschaftspolitische Strategien und Strukturprobleme," op. cit.

55. Guangzhou tongjiju xinxi wang, www.gzstats.gov.cn; Guangzhou nianjian (Guangzhou Yearbook) 2010, www.guangzhou.gov.cn/node_450; Gao Zhiyong, Zhong Shixiao, "Guangzhou tiaokong xize qianghua baozhangfang jianshe" (Emphasise the pragmatic, Guangzhou's regulations strengthen the construction of welfare housing), Fangdichan baokan, №. 6, 2010, p. 22.

56. "Zhengfu shi 4300 yuan $/ \mathrm{m}^{2}$ huigou fuli Jinshazhou lianzufang" (The Government tries to repurchase subsidized rental apartment of Jinshazhou's Fuli estate for 4300 yuan $/ \mathrm{m}^{2}$ ), 23 November 2011, original: Xinkuaibao, www.news.dichan.sina.com.cn/2011/11/23/408645.html (accessed on 19 March 2013); "Xianjiafang bian shangpinfang - yin maidi zai xian zhengce zai hou" (Limited-priced houses become commodity houses - this is because selling land is more important than the policy), Nanfang dushibao, 30 September 2011, www.gz.house.sina.com.cn/ news/2011-09-30/06413892414.shtml (accessed on 19 March 2013); "Guangzhou zui da xianjiafang bianshen putong shangpinfang" (Guangzhou's biggest limited-priced housing project becomes normal commodity housing), Nanfangwang, 27 October 2009, www.news.dichan.sina.com.cn/gz/2009/10/27/77902.html (accessed on 19 March 2013).

57. "Zhengfu shi 4300 yuan $/ \mathrm{m}^{2}$ huigou fuli Jinshazhou lianzufang," op. cit:; Zhao Yanhua and Fan Shuyi, "Shichang cuonong xianjiafang zhengce?" (Is the market playing with the limited-priced housing policy?), Yangcheng wanbao, 15 July.2009, www.ycwb.com/ePaper/ycwb/html/200907/15/content_544075.htm (accessed on 19 March 2013).

58. John Logan et al., "The winners of China's urban housing reform," op. cit.; Li Siming and Zheng Yi, "Financing home purchase in China, with special reference to Guangzhou," Housing Studies, Vol. 22, No. 3, 2007, pp. 409-425.

59. Li Siming, "Housing consumption in urban China: A comparative study of Beijing and Guangzhou," Environment and Planning A, Vol. 32, 2000, pp. 1115-1134

60. Guangzhou nianjian (Guangzhou yearbook) 2009, www.guangzhou.gov.cn/node 450/node_724/2009 nj/html/0921.htm (accessed on 5 February 2013).

61. Zhou Chunshan and Luo Yan, "Jin 10 nian Guangzhou shi fangdichan jiage de kongjian fenbu ji qi yingxiang" (The spatial distribution of real estate prices in Guangzhou in the last decade and its effects), Tudi liyong, Vol. 28, No. 3, 2004, pp. 52-56.

62. Soufun.com Ltd., www.gz.soufun.com; Anjuke Inc., www.guangzhou.anjuke.com; Sohu.com Inc., www.gz.focus.cn; Fangjia wang, www.gz.fangjia.com.

63. Fangjia quanwei baogao - 2000 zhi 2012 nian Guangzhou fangjia quan shoulu (Authority report on housing prices. A complete presentation of Guangzhou's housing prices 2000-2012), www.dichan.sina.com.cn/gz/zt/gzfdc/index. shtml (accessed on 14 March 2013); Guangzhou shi Guotu Ziyuan he Fangwu Guanliju, 2008 nian 12 yue ji 2009 nian yuandan qijian Guangzhou shiqu fangdichan jiaoyi dengji qingkuang tongbao, op. cit. To be comparable to the statistics, the calculation of our sample's average is based on ten districts and does not include villas. 


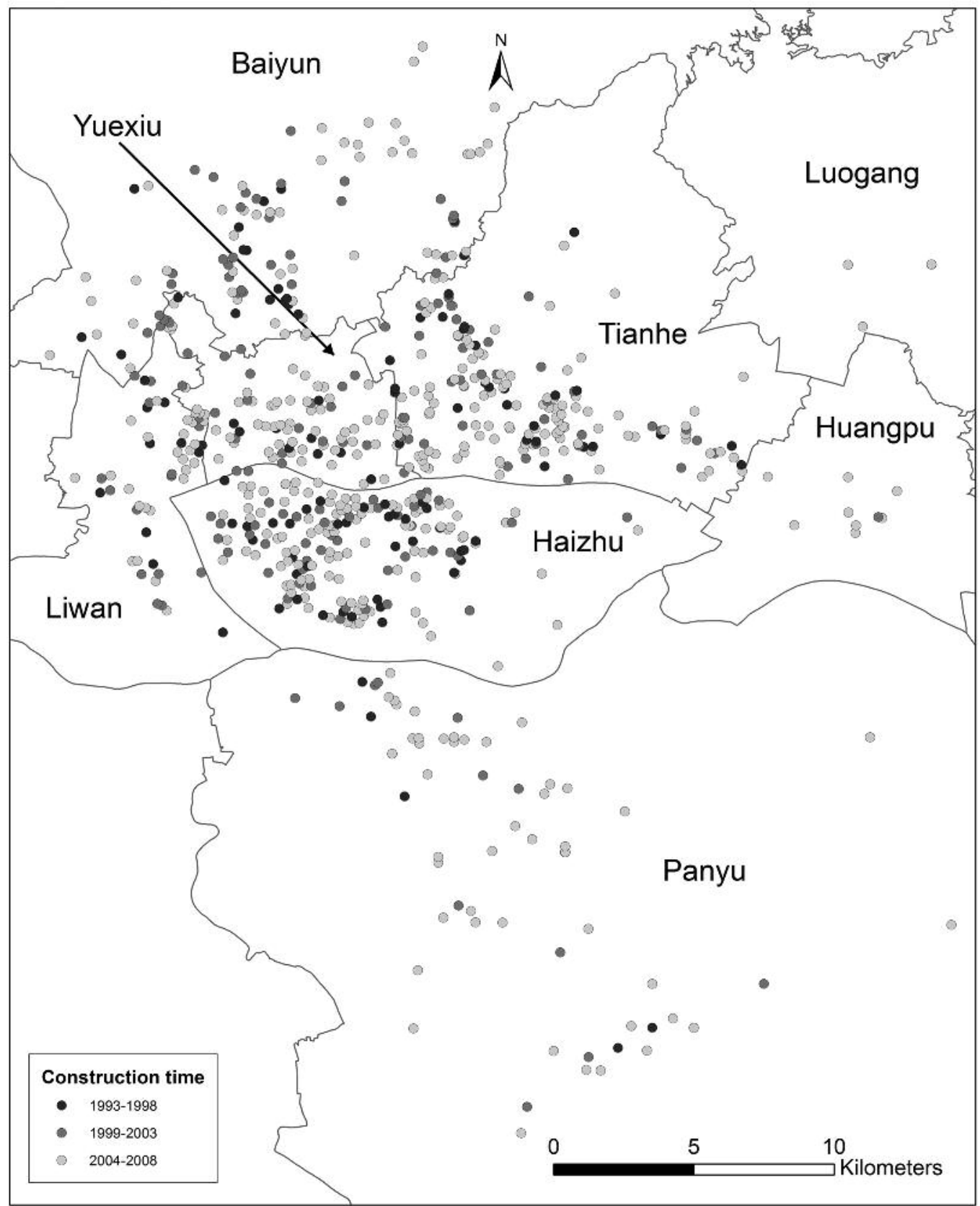

Data sources: www.gz.soufun.com; www.guangzhou.anjuke.com; www.gz.focus.cn; www.gz.fangjia.com

official real estate statistics use actual transaction prices (chengjiao jia 成 交价), calculated as sales volume divided by the size of sold residential space. According to $\mathrm{Wu}(2002)$, there is a deviation of about $10 \%$ between asking and transaction price due to bargaining and discounts. ${ }^{(64)}$ One might speculate that this percentage was higher in a time of economic crisis. Moreover, not all the expensive apartments included in our sample will have found a buyer, and some - perhaps cheaper - transactions may not have relied on real estate agents as middlemen. Overall, our snapshot seems to be reasonably embedded in the general trend. Even existing seasonal fluctuations will not significantly change the relative distribution of lowend and high-end housing, and it is mainly this relationship and its spatial representation that we are interested in. What is not immediately possible is the derivation of trends from snapshot data. However, some conclusions can be drawn when we look separately at housing estates of different building periods and their respective spatial distribution.

\section{Categorisation and mapping}

For our analysis, we need to define categories of estate age and price levels. We want to use the estate age to demonstrate residential development over time. The three categories in Map 1 follow the phases of

64. Wu Fulong, "Sociospatial differentiation in urban China: Evidence from Shanghai's real estate markets," Environment and Planning A, Vol. 34, 2002, p. 1596. 


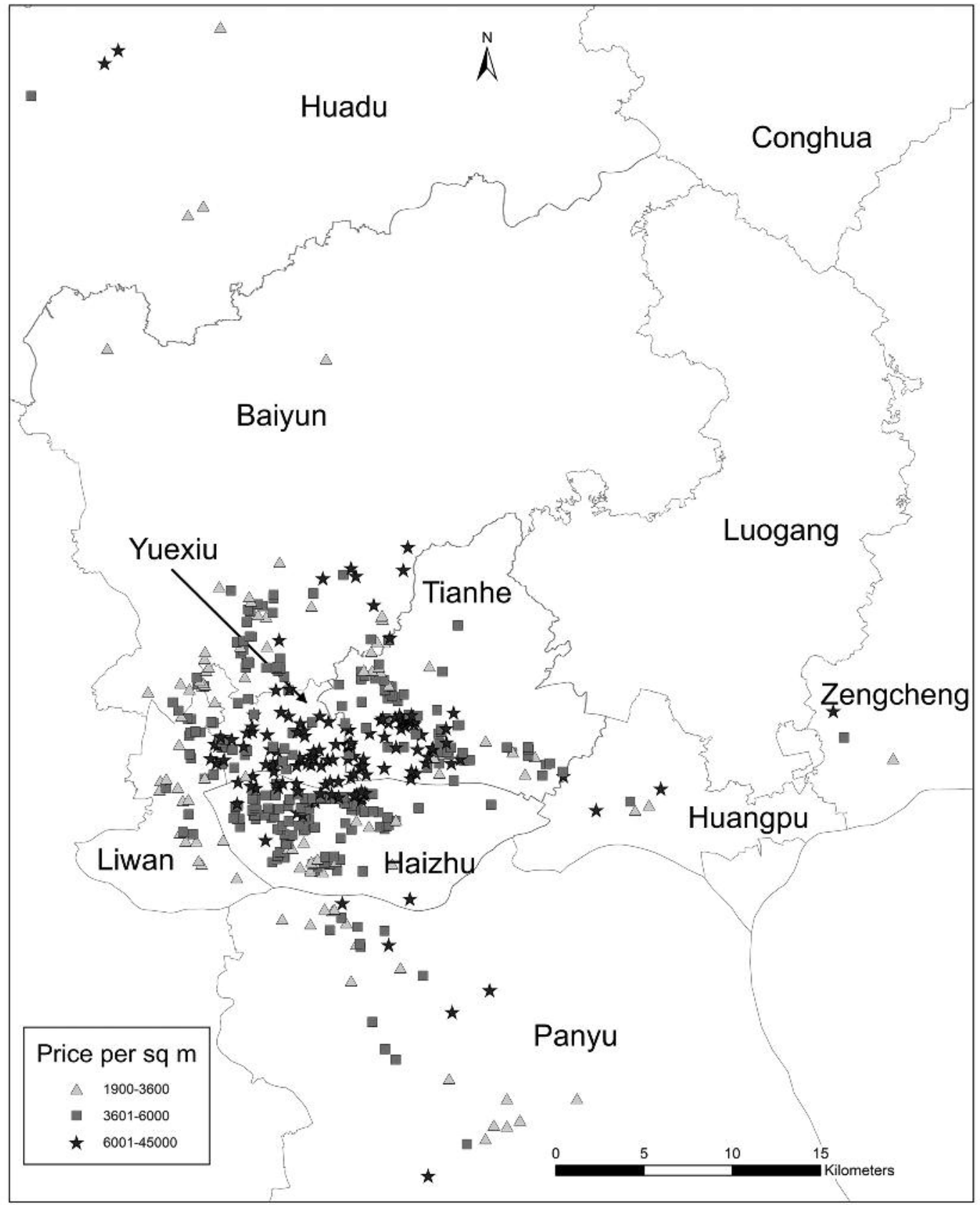

Data sources: www.gz.soufun.com; www.guangzhou.anjuke.com; www.gz.focus.cn; www.gz.fangjia.com

housing markets and policies: 1993-1998: The socialist housing welfare system, with the radical policy change in 1998 as its turning point; 1999-2003: gradual implementation of the capitalist housing market policies; 2004-2008: full implementation of housing reform. Since our data was collected in 2008, it might not fully reflect market dynamics during the previous phases. Therefore we crosschecked our findings with district-level real estate statistics. ${ }^{65)}$

We also need price categories to define which price range can be considered "cheap" or "expensive," low-, middle-, or high-priced. Without doubt, these categories are quite flexible, changing over time and with the socio-economic status of the buyer. As a rough reference point we use the concept of affordability. A common method is to define affordability as "financial capacity of a household to purchase or rent a housing unit" (66) and to calculate it as the ratio between income and housing costs. Opinions differ on which part of income counts as spendable, what should be included in housing costs, and most importantly which ratio qualifies as bearable. The World Bank, for example, sets an income-housing ratio of 3:1 to 6:1 as affordable. ${ }^{(67)}$ In China,

65. Guangzhou fangdichan nianjian (Real estate yearbook Guangzhou) 2001 and 2008, Nianjianshe, 2001/2008.

66. Economic Commission for Europe, Guidelines on Social Housing - Principles and Examples, United Nations, 2006, p. 68, www.unece.org/fileadmin/DAM/hlm/documents/2006/ece/hbp/ECE. HBP.137.pdf (accessed on 5 February 2013).

67. David J. Hulchanski, "The concept of housing affordability: Six contemporary uses of the housing expenditure-to-income," Housing Studies, Vol. 10, No. 4, 1995, pp. 471-491; Lau Kaman and Li Siming, "Commercial housing affordability in Beijing, 1992-2002," Habitat International, Vol. 30, No. 3, 2006, pp. 614-627. 


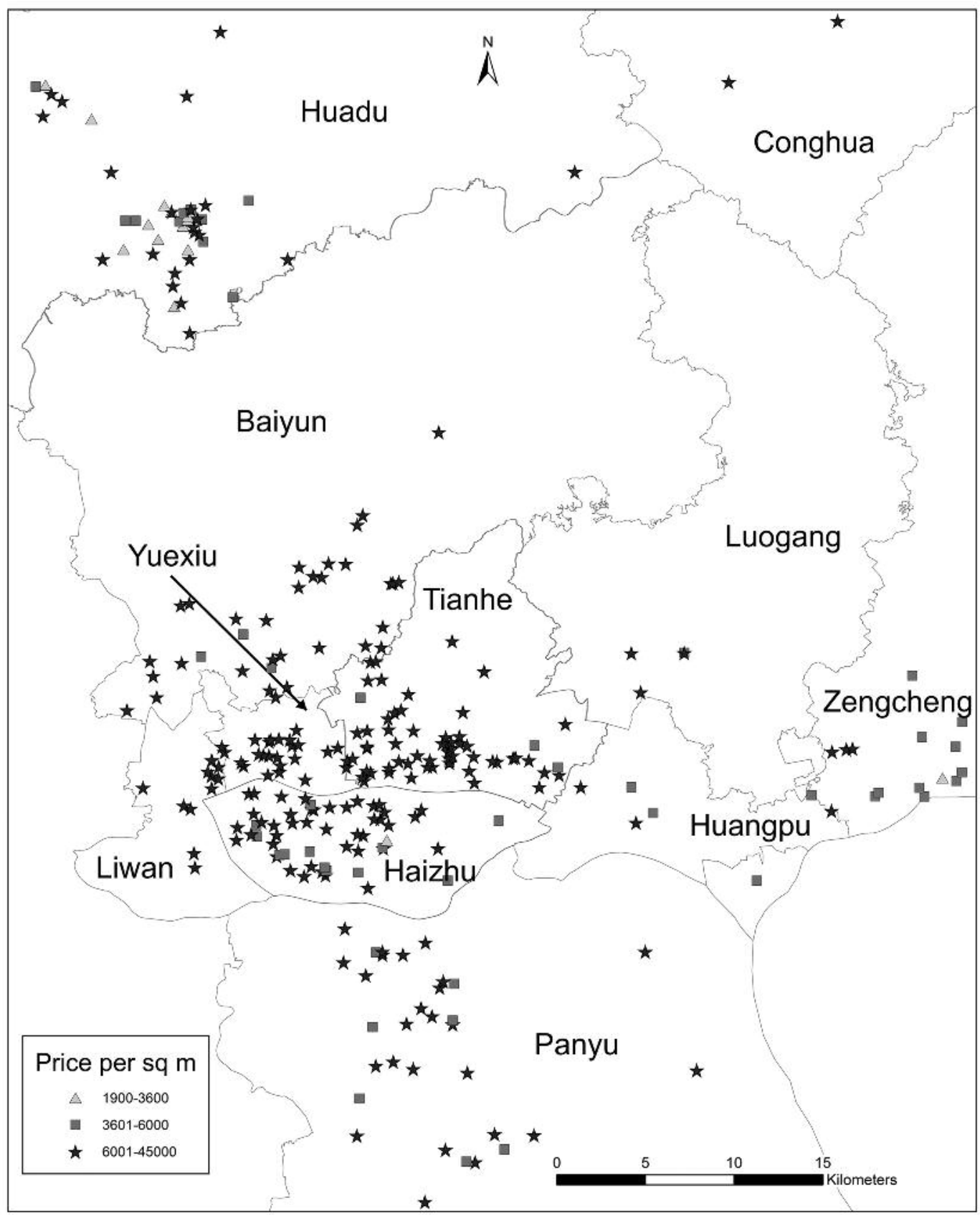

Data sources: www.gz.soufun.com; www.guangzhou.anjuke.com; www.gz.focus.cn; www.gz.fangjia.com

the national annual income-to-housing unit ratio in 2009 was 9:1, compared with 3:1 in the US and 7:1 in Australia. (68) Mak et al. (2007) point to the great differentiation within China, with Shanghai's ratio of 14:1 vs. Guangzhou's ratio of 6:1 at the beginning of the millennium. ${ }^{(69)}$ Chen et al. (2010) emphasise the validity of this approach and see the relation between annual income and housing unit price as the precondition of housing access, since mortgages and loans are granted by similar calculations. ${ }^{(70)}$

If we were to solidly discuss affordability measures, we would need to include a discussion of "income" in the Chinese context, where often several sources of variously documented monetary income and non-monetary benefits contribute to people's livelihood. In our case, we are not interested in affordability per se but only as a reference for our categorisation. While it is unavoidable to set a certain threshold, we define a price span rather than a fixed limit. A common way is to base the calculation on median household income. Lacking this data, our starting point was the middleclass's average spendable income per capita in Guangzhou in 2008. With this figure at 24,899 yuan, ${ }^{(71)}$ and 3.2 people composing an average

68. Ling Shen, "Are house prices too high in China?", China Economic Review, Vol. 23, No. 4, 2012, p. 1207.

69. Stephen W.K. Mak et al.," "Privatization, housing conditions and affordability in the People's Republic of China," Habitat International, Vol. 31, No. 2, 2007, p. 184.

70. Jie Chen et al., "Assessing housing affordability in post-reform China: A case study of Shanghai," Housing Studies, Vol. 25, No. 6, 2010, pp. $884 \mathrm{ff}$.

71. Guangzhou nianjian 2009 (Guangzhou yearbook 2009), www.data.gzstats.gov.cn/gzStat1/ chaxun/njsj.jsp (accessed on 6 February 2013). 
household (urban hukou and permanent migrants included), (72) the mean household income would be 79,678 yuan per year. Based on the above understanding of affordability, we define apartment prices below the priceincome ratio of 4:1 as "low-priced," up to a 6:1 ratio as "medium-priced," and beyond this as "high-priced." What is more difficult is to apply this logic to square meter prices. Our data covers a broad range of building sizes. Apartments sold in 1993 measured $91 \mathrm{~m}^{2}$ on average, ${ }^{(73)}$ while those in 2005 measured $116 \mathrm{~m}^{2}$ (related to all urban districts in respective years). ${ }^{(74)}$ Moreover, most apartments were smaller than the average. Therefore we assume a standard dwelling size of $95 \mathrm{~m}^{2}$ for our calculation. This gives us affordability limits of 3,354 yuan and 5,117 yuan per $\mathrm{m}^{2}$. Given the uncertainties in this calculation, we can safely round these figures up and define a square meter price range of 1,900-3,600 yuan $/ \mathrm{m}^{2}$ as low-priced, $3,600-6,000$ yuan $/ \mathrm{m}^{2}$ as medium-priced and 6,000-45,000 yuan $/ \mathrm{m}^{2}$ as high-priced.

In order to keep a relatively clear visual result, we leave it at three categories for each of the three following maps, which show the district boundaries of Guangzhou and each of the estates located by exact address. Very few estates are located outside the map area in remote suburbs, and a number of others appear invisible due to overlapping. For our analysis, however, we could refer to larger and complete maps. It is noted that the symbols for the estates are of the same size, irrespective of the size of the actual estate. Due to their larger size, suburban estates therefore appear underrepresented.

\section{Spatial distribution of commodity housing in Guangzhou}

The historical urban core of Guangzhou includes what are today Yuexiu and the northern parts of Liwan and Haizhu. The wider inner city extends beyond the full territories of these three districts to include Tianhe and the south of Baiyun. The remaining districts cover suburban and periurban space, especially in the case of the two officially "rural" county-level cities of Conghua and Zengcheng. Within the overall administrative area of Guangzhou of 7,434 $\mathrm{km}^{2}$, the area of the urban districts grew from 1,443 $\mathrm{km}^{2}$ in 1993 to about $3,800 \mathrm{~km}^{2}$ in 2008. ${ }^{(75)}$ Map 1 indicates that most people still live in the old districts, and new development concentrates here as well as on immediately adjacent areas. Additionally, some individual clusters emerge in the suburban areas. The districts are often taken as geographical references, but the maps show clearly that the locations of development do not follow administrative borders, and districts therefore do little to clarify related spatial developments.

In the 1990s, centralised locations were very clearly favoured over suburban ones. The relatively low car-ownership rate and insufficient transport infrastructure were major reasons, but not the only ones. Innercity locations are also preferred because of better access to prestigious institutions such as hospitals and especially schools. Additionally, before 2002, many of today's suburbs did not yet belong to Guangzhou, which meant residents did not have full access to the superior urban resources of the provincial capital.

Map 1 shows a trend of suburbanisation. The older estates in our sample (built in 1993-1998) are mostly located in the inner city, at the fringe of the old core. Before 1998, there was little development within the old core and even less in the suburbs. Some notable exceptions are located in suburban Panyu, which early on benefitted from Hong Kong real estate investment.
The distribution of estates built between the decision to abolish welfare housing (1998) and the beginning of the building boom (2004) was not fundamentally different, although the radius from the old core increased a bit. It was only after 2004 that a large number of estates also emerged on more centrally located sites - often at the expense of historic quarters, especially in Yuexiu. Suburbanisation also became more obvious during that phase. Many of the post-2004 estates in this category are located in Panyu, Baiyun, Huangpu, and even more remote locations such as near the new airport in Huadu.

\section{Distribution of commodity housing estates by price- level}

The first finding when looking at the collected price data is a markedly wider price range between cheap and expensive estates in the newest generation of estates compared to older ones. This is partly due to the fact that most of the apartments in the older estates were second-hand property in 2008, and most of those in the latter category were new ones. But this alone cannot explain the large price spread for the 2005-2008 category. It is in the first place a sign of a more differentiated market especially a growing luxury market. On our affordability scale, $58.6 \%$ of new commodity housing estates qualify as high-priced, while only $9.3 \%$ qualify as low-priced, and $32.1 \%$ as medium-priced. The market has produced a price structure of commodity housing that is biased towards the upper end (Map 3).

In terms of spatial distribution, Guangzhou is often described as a perfect example of classic space theories: an expensive core encircled by concentric layers of decreasing prices. ${ }^{(76)}$ Map 2 shows commodity housing estates built in 1993-2004 and their average asking price per square meter in 2008. The most expensive segment $\left(6,000-45,000\right.$ yuan $\left./ \mathrm{m}^{2}\right)$ was concentrated in the city centre, in Yuexiu and the Southwest of Tianhe. Some estates in the medium-priced category $\left(3,600-6,000\right.$ yuan $\left./ \mathrm{m}^{2}\right)$ were located in a ring around the centre: from west of Haizhu to south of Baiyun and west of Tianhe. Cheaper housing (1,900-3,600 yuan/m²) was available south of Haizhu and Liwan, in Tianhe and Baiyun, and further away in Panyu, Huangpu, and Huadu.

The commodity housing estates built in 2005-2008 showed a less obvious ring structure. On the one hand, the centre (especially Yuexiu and Tianhe) still attracted the most expensive estates, while on the other hand many high-priced estates could now also be found in adjacent areas and remote development zones. They extend further into Baiyun, Haizhu, Huadu, and Panyu. These areas now attract housing at different price levels. In 2005,

72. Guangzhou tongji nianjian 2009 (Guangzhou statistical yearbook 2009), www.data.gzstats. gov.cn/gzStat1/chaxun/njsj.jsp; www.data.gzstats.gov.cn/gzStat1/chaxun/njsj.jsp (both accessed on 5 February 2013).

73. Guangzhou nianjian 1994 (Guangzhou yearbook 1994), www.guangzhou.gov.cn/yearbook/ 20year/html/13829.htm (accessed on 5 February 2013).

74. Guangzhou fangdichan nianjian 2006 (Real estate yearbook Guangzhou 2006), Nianjianshe, 2006, p. 164.

75. Guangzhou nianjian (Guangzhou yearbook) 1994 and 2009, see: www.guangzhou.gov.cn/ node_450/ (accessed on 11 April 2013).

76. Zhou Chunshuan and Luo Yan, "Jin 10 nian Guangzhou shi fangdichan jiage de kongjian fenbu ji qi yingxiang," op. cit:; Zheng Zhiqing, "Guangzhou shangpinfang zhuzhai jiage fenbu tezheng yanjiu" (Research on the characteristics of distribution of commodity housing prices in Guangzhou), Redai dili, Vol. 21, No. 1, 2001, p. 21; Zhang Rong, Guangzhou shangpin zhufang fazhan dui chengshi kongjian jiegou yingxiang de jiegou (The influence of Guangzhou's commercial residential housing development on the urban spatial structure), doctoral thesis, Sun Yatsen University, 1997. 
the transport infrastructure and other factors had already improved to an extent that living in suburban locations had become sufficiently attractive to a whole range of social groups. Families who could not afford to live in urban commodity estates now resided side-by-side with the well-earning, mobile middle class who prefers the spacious, safe, and quiet environment of suburban gated communities. For the former, distance translates into lower housing prices, for the latter, into better living conditions.

The two maps together, including newer as well as older housing options, do not fully support fears of segregation and polarisation. Considering the big price differences between newly-built and second-hand housing, there is a mixed price structure in the central districts and even more so in the adjacent areas. Commodity housing in the old core has not been implemented through any large-scale residential redevelopment programme, but rather added to the existing structures. This occurred especially in the eastern section of the urban core (Yuexiu) and to a lesser degree in the western section (Liwan). Large areas of the old town were for a long time avoided for redevelopment, because bargaining with residents on compensation and resettlement is a tough and expensive exercise. The increasing availability of suburban sites after the administrative expansion and after implementation of an improved transport infrastructure has further reduced pressure on the older urban areas and has allowed poorer quarters to remain next to the increasing number of new ones. As mentioned above, the suburban sites have attracted an equally mixed clientele - looking for either cheaper options or more luxurious places - but the mix there is less fine-grained, if only because suburban estates are much larger than those in the inner city.

\section{Conclusions}

The results should be interpreted first within the commodity sector and then with a view beyond this sector. Within the commodity sector, we have seen differentiation and an increasing price range. The most obvious finding - also setting our case apart from the Western experience - is the continuing preference for inner-city sites for high-end developments. There are a number of practical, cultural, and political reasons for this, which have briefly been discussed. On the other hand, suburbanisation is also highly visible from the maps. It is very obvious that for the suburban estates, location still matters. Due to their varying accessibility, infrastructure, and image, specific suburbs attract different price levels. Segregation and differentiation appear stronger in the suburbs, because estates there are larger and more strictly gated.

In the inner city, conversely, the degree of mixing appears much higher than district-level analyses would suggest. If considering only the commodity market at scale of the estate, these estates are small, less gated, and distributed in a rather mixed fashion.

The picture becomes even more heterogeneous when other housing options are included. Urbanised villages (chengzhongcun 城中村) (77) and old urban housing stock lie equally intermixed among the commodity estates. This notably does not mean that people necessarily mix - our further research actually casts doubt on this - but that the conditions for a mixed and integrated city are comparatively good. This finding puts claims of increasing segregation into perspective. Even though our analysis concentrates on commodity housing, because this is about to become the dominant sector, we have to see that in 2008 , commodity housing accounted for only $40 \%$ of Guangzhou's residential units. ${ }^{(78)}$ This is not a small number, and it is rapidly growing, but clearly many low-income neighbourhoods in the city are not covered by our survey. Those urbanised villages, former danwei compounds, or pre-socialist houses still provide housing space to low-income residents - and they provide this space right near the city centre with excellent accessibility and in a relatively mixed social environment. The problem is that these housing options are all gradually vanishing. It is therefore time to ask whether the mechanisms of the commodity sector are suitable for catering to the whole city and to all social groups. The experiences so far are not encouraging.

The markets have produced a price structure that is biased towards the upper end and tends to create segregated socio-spatial structures. Although central areas such as Yuexiu and Tianhe are still socially mixed, the trend is towards a homogenisation and dominance of unaffordable commodity housing. On the other hand, separate suburbs for high-class gated communities and for displaced poorer residents from erased inner city neighbourhoods have emerged.

Despite the undisputable success of housing reform and the massive involvement of private capital, it is an open question whether it will work equally well without alternative housing modes. The state would probably be well advised not to do away with urbanised villages and old urban neighbourhoods and to remain active as a regulator and builder to provide affordable housing and a reasonably mixed socio-spatial structure. The markets will not do this on their own.

\section{Ryanne Flock is a PhD candidate at Freie Universität Berlin.}

Koserstraße 20, 14195 Berlin, Germany (flock.ry@googlemail.com).

I Werner Breitung is a professor at Xi'an Jiaotong-Liverpool University in Suzhou.

No.111 Ren'ai Road, Suzhou Dushu Lake Higher Education Town, Suzhou Industrial Park, Suzhou, China (breitung@gmail.com).

I Li Lixun is a professor at Sun Yat-sen University. Sun Yat-sen University, School of Geography and Planning, 135 Xingang Xi Lu, Guangzhou 510275, China (eesllx@mail.sysu.edu.cn).

77. Lin Yaliu, "Understanding the 'village in the city' in Guangzhou: Economic integration and development issues and their implications for the urban migrant," Urban Studies, Vol. 48, No. 16, 2011, pp. 3583-3598: p. 3588.

78. www.gzstats.gov.cn/tjnj/2008nj/2008/8-9.htm (accessed on 12 February 2013). 